\title{
Lip Basal Cell Carcinoma
}

National Cancer Institute

\section{Source}

National Cancer Institute. Lip Basal Cell Carcinoma. NCI Thesaurus. Code C8014.

A basal cell carcinoma arising from the lip. 